\title{
'Senses': Assessing a Key Term in David Chidester's Analysis of Religion ${ }^{1}$
}

\author{
Johan M. Strijdom \\ strijjm@unisa.ac.za
}

\begin{abstract}
The purpose of this article is to illustrate and assess Chidester's use of the 'senses' as an analytical term in his study of religion. Under 'senses' Chidester includes not only the five conventional senses of Aristotle, but also analyzes metaphorical uses of the senses in religious discourse, the visions and dreams of mystics and shamans, and eventually new media as extensions of the human senses. Chidester's analysis of the senses in European Christian discourses on the one hand, and in colonial and postcolonial African indigenous religion and imperial religious studies on the other hand, is compared and assessed. Although he does not offer a systematic comparison of these case studies, I argue that his analysis lends itself to an explicit comparison of the senses as material aspects of religion and show how his contextualized and historically nuanced analysis of the senses in religion and religious studies informs a critical study of religion. Since critical assumes judgment, values need to be explicated in terms of critical theories, which in my view need further elaboration.
\end{abstract}

Keywords: senses, visions, dreams, media, analytical terms in religious studies, critical theory, interior senses in medieval European theories and practices, African indigenous religions

\footnotetext{
1 I would like to thank the two anonymous peer-reviewers, whose constructive comments helped me to refine aspects of this article.
} 


\section{Johan M. Strijdom}

\section{Introduction}

In theorizing 'the senses' as an analytical category in the study of religion, Birgit Meyer and Jojada Verrips (2008:20-30) have briefly traced the Western genealogy of the term 'aesthetics'. The Kantian legacy in Western modernity, they argue, has limited the meaning of the concept of aesthetics to the rational comprehension of beauty and the sublime. It prioritized the mind/reason and high art for the elite few, and relegated to an inferior position the body and the senses, popular art labeled as 'kitch', and religion conceived of as irrational which was supposed to gradually decrease in importance due to modern secularization.

Against this narrow definition from the Enlightenment that limits aesthetics to beauty, stands Aristotle's broader conceptualization of aesthetics as involving the five senses of the body. The recovery and development of this view, particularly in Merleau-Ponty's phenomenology of perception in the late 1940s, has influenced the agenda of a number of researchers in the humanities, which has opened the possibility to account for the role of the body, the senses, and objects not only in high art but also in the everyday life of people, and furthermore to produce innovative knowledge on their role in religion and in the academic study of religion. It would be crucial, they emphasize, to include a socially and culturally sensitive contextual analysis of "ways in which the tuning of the sensorium has undergone actual transformations under the influence of the invention of new technologies', such as audio cassettes, radio, television, photography, and cyberspace that have profoundly impacted the formation of modern subjectivities (Meyer \& Verrips 2008:24).

Although a great deal of recent research on the senses in religion has focused on visual media (e.g. the bodily and affective engagement with Jesus pictures in American popular Protestantism, or with mass-produced images of deities in Indian villages to render the power of the gods present), the impact of auditory media on the emotional and moral formation of subjects has also received attention (e.g. the shared listening of young Muslims to massproduced cassette sermons) $)^{2}$.

In taking the body and the senses as points of departure, they conclude, the intention is not to replace the modern binary hierarchy with a new one that would simply prioritize the body and the senses over the mind, or practices

2 See the discussion of Morgan (1998), Pinney (2004), and Hirschkind (2006) in Meyer and Verrips (2008:25-26). 
over beliefs, popular art over high art, and religion over art, but to understand that the mind in a very concrete way always involves the body and the senses. The task, therefore, is to see the mind as embodied and grounded in matter, and to study religion by integrating ritual practices and beliefs, the senses and thought, the 'body and mind as an undivided whole' (Meyer \& Verrips 2008:29), and importantly, to understand as inextricably intertwined the individual self and social collectivities that are formed by means of shared aesthetic practices ${ }^{3}$.

In summary, Meyer and Verrips (2008:27-28) highlight three overlapping aspects in this paradigm shift in the study of religion:

- the encounter with the divine and each other is necessarily mediated through the physical senses, while the specific, legitimate ways in which the senses mediate the encounter with the transcendent are authorized by religious traditions;

- the individual self is formed through habitual uses of the bodily senses (not only of seeing and hearing, but also of touch, smell, and taste); and

- groups in which people feel at home, i.e. collective identities, are formed by shared uses of the embodied senses (e.g. by looking at images in a certain way, or singing the same songs), which also play a key role in their appearance in public, secular spaces - an aspect, they note, that needs further investigation in future.

The role of the senses in religion and comparative religious studies, as part of what would become known as the material turn in the academic study of religion ${ }^{4}$, has preoccupied David Chidester for almost forty years in his study

3 Houtman and Meyer (2012) insist that part of this move is the realization of the role of religion in public life (rather than limited to the inner life of the individual as modernity has constructed its role).

4 Drawing on Houtman and Meyer (2012), I listed in an article (Strijdom 2014a) the following as aspects to be studied under material religion:

- objects like relics, amulets, dress codes, painted or sculpted images, written words and architectural spaces;

- feelings and sensory experiences like seeing, hearing, smelling, tasting, and touching; and

- bodily performances in specific gestures, rituals, ceremonies, and festivals. 


\section{Johan M. Strijdom}

of religion - a theme that he not only pioneered in his doctoral thesis in the late 1970s, but has also developed since then.

My purpose is to use the theorization of 'the senses' by Meyer and Verrips in their mentioned article ${ }^{5}$ as frame of reference to articulate ways in which Chidester's attention to 'the senses' in selected case studies from his oeuvre illustrates his innovative contribution, and to indicate a way in which his analysis may be taken further.

Under 'senses' as analytical category, Chidester examines not only views of the five senses of Aristotle, but also the metaphorical uses of the senses in religious discourse, the visions and dreams of mystics and shamans as extraordinary 'internal/interior senses', and new media as extensions of the human sensorium 6 .

To theorize the concept of 'the senses' in more depth, Chidester engages in Word and light, published in 1992 as the revised version of his doctoral thesis, with theories of the body and 'the senses' - particularly of seeing and hearing - in the work of, amongst others, phenomenologists (Merleau-Ponty and Hans Jonas), anthropologists (Lévi-Strauss and Mary

\footnotetext{
Marx's insight that religion is materially based is crucial to the material study of religion in Chidester (2018:10): 'The material dynamics of categories, formations, and circulations reveal different dimensions of Marx's rendering of the "spiritual intercourse" of human beings as an "efflux of their material condition". Tracing the genealogy of the concept of material religion a bit further back to Feuerbach, Chidester (2015:374) underlines that for Feuerbach 'human consciousness is not an independent spiritual essence, aloof from the material world of objects', but that '[a]gainst any idealist rendering of humanity, Feuerbach argued that human beings were constituted by their reciprocal engagements with material objects'. Far from neglecting the transcendental in his study of religion, Chidester takes it very seriously as a human construct with a material base that has real consequences in the world - as he has demonstrated extensively in his case studies of religion under colonial and postcolonial conditions. The potential of using material terms to produce innovative knowledge in the academic study of religion is emphasized by Chidester (2000b).

5 In this article I do not engage with developments of the theme elsewhere in the oeuvre of Meyer and Verrips. My strategy limits itself by focusing only on this specific article by them in order to introduce my discussion of the senses in Chidester's work and highlight his contributions in terms of their article.

6 Marshall McLuhan (1964) is usually credited with conceptualizing the media as extensions of the senses.
} 
Douglas), and literary theorists and philosophers (Northrop Frye, Walter Ong, Derrida, and Foucault). From Word and light (Chidester 1992) up to a recent introduction to articles by a number of his postgraduate students in the Journal for the Study of Religion (Chidester 2013), Chidester has consistently maintained that our best hope to produce new knowledge about religion and religions probably depends on the application of theorized key concepts to selected case studies ${ }^{7}$.

In this paper I will engage with Chidester's theoretically informed application of 'the senses' as an analytical category to case studies from

- European Christian discourses until the Protestant Reformation; and

- South African indigenous traditions, notably $19^{\text {th }}$-century indigenous Zulu dreaming under colonial conditions and its interpretation in imperial theories of religion, as well as contemporary Zulu neoshamanism within a global context ${ }^{8}$.

7 In his most recent Religion: Material dynamics, Chidester (2018) demonstrates how he has in his academic career given key terms theoretical depth and applied them to case studies to yield innovative insight in the academic study of religion. One of the anonymous reviewers of this article commented that my statement might create the impression of 'a top-down approach, from theory to case studies', and wondered whether 'Chidester also thinks that case studies help to produce theory'. From my reading of Chidester, it seems clear that he begins with broad definitions of key concepts and considers prominent theories of a concept, then refines them as he applies them to case studies. See, for example, Chidester's statement in the concluding chapter of Religion: Material dynamics (Chidester 2018:208): 'Certainly, these generalizations about classifications and orientations in the dynamic materiality of religion are painted broadly, with a very broad brush. The specific cases we have engaged in this book, dwelling in detail, have suggested some ways in which the brushstrokes might be refined. However, in the art of studying religion, we all benefit from critical and creative reflection on the categories we employ for thinking about religion'.

8 For the first case study, Light and word: Seeing, hearing and religious discourse (Chidester 1992) and Christianity: A global history (Chidester 2000a) will constitute the primary sources, and for the second case study Authentic fakes: Religion and American popular culture (Chidester 2005), Wild religion: Tracking the sacred in South Africa (Chidester 2012), Savage systems: Colonialism and comparative religion in Southern Africa (Chidester 1996), and Empire of religion: Imperialism and comparative religion (Chidester 2014). 
Although Chidester does not offer a systematic comparison of these case studies, I will argue that his analysis does open the possibility to develop a critical comparison of the role of the senses as material aspects of religion in these cases from different times and locations. His contextualized and historically nuanced analysis of the senses in religion and in religious studies, I will argue, may inform a critical approach to the academic study of religion. However, since critical assumes judgment on the basis of normative values rather than contentment with a mere phenomenological description, I will in conclusion argue that these values, particularly regarding social boundaries and economic exchange, need further explicit and consistent elaboration ${ }^{9}$.

\section{First case study: The 'senses' in European Christian discourses until the Protestant Reformation}

In Word and light, Chidester (1992) argues that metaphorical uses of seeing and hearing in religious discourses ${ }^{10}$ are closely related to the physical senses of seeing and hearing themselves and to ways in which they are conceptualized and given meaning in cultural traditions ${ }^{11}$. "Within this dialectic in the symbolic discourse of the body', he maintains, 'perceptual metaphors are

9 Chidester, in Word and light and often elsewhere in his work, tends towards a phenomenological description and refrains from critical judgment. In other cases, however, he does make normative judgments, e.g. in his application of the term 'sociality' to exclusionary and inclusive boundary formations in the old and new South African system of religion education, or in his application of the term 'exchange' to Rock ' $n$ ' Roll in Authentic fakes (Chidester 2005). My argument is that scholars of religion should not be content with a phenomenology of religion that pretends to offer neutral descriptions but should explicate their normative frameworks and consistently apply these to their analyses.

10 Chidester (1992:xii) emphasizes that his analysis in Word and light deals mostly with discourse and not with ritual practices, institutions, and politics. The latter aspects of religion receive extensive attention in his later works.

11 Although Chidester's focus in Word and light is on the Christian tradition, in its conclusion he does remark on the relevance that a phenomenology of perception may have for the analysis of perceptual metaphors in Judaism, Islam, Hinduism, Ch'an Buddhism, Chinese popular religion, and Daoism (cf. Chidester 1992:135143). 
generated by the body, articulated in discourse, but always forced back again to their physiological ground in the lived experience of the body' (Chidester 1992:128).

To analyze uses of 'the senses' and perceptual metaphors in European Christian discourses, he therefore develops a theoretical framework that draws on ancient Greek theories of the senses which have profoundly influenced European Christian discourses, as well as on insights from $20^{\text {th }}$-century phenomenologists, anthropologists, literary theorists, and philosophers. He concludes, on the basis of his survey, that the physical senses of seeing and hearing connote two different orientations to the world, which necessarily inform different associations that their uses as metaphors convey in expressing a relationship between humans and the divine. If, on the one hand, 'seeing' tends to be associated with spatial continuity, immediate presence, copresence, and contemplation, 'hearing' on the other hand tends to connote temporal discontinuity, change, difference, indirect representation, and action.

In applying this framework to selected case studies from European Christian discourses until the $16^{\text {th }}$ century, Chidester identifies two fundamental patterns: One of conflict, and another of synesthesia.

Uses of metaphors of hearing and seeing in the Trinitarian controversy of the early $4^{\text {th }}$ century exemplify for Chidester the first pattern. Whereas Arius emphasized the Logos as divine Word, Athanasius prioritized Phōs as divine Light. With the latter position being victorious, one consequently finds in the Nicaean Creed only 'Light from Light' with no mention of the Logos. The one side insisted on verbal discontinuity (homoiousios) and the other side on visual continuity (homoousios). The perceptual metaphors used by the two groups thus served to express the theological conflict between the two factions. 'The contestants', Chidester (2000a:50) concludes, 'appropriated one or the other of those models in order to claim legitimate ownership of a symbolic universe in which both word and light operated'.

The other pattern, characterized by synesthetic metaphors that disrupt language to express an intense experience of mystical union with the divine, is for Chidester exemplified by Philo and Augustine. In Philo, God's Word is seen at the crucial moment when Moses receives the Torah ${ }^{12}$. Also in

12 Another example of synesthesia is found among $4^{\text {th }}$-century Christian monks in the Egyptian desert, whose senses of hearing and seeing fused in an intense spiritual experience. As if drunken, they saw their founder, Pachomius' words flying from 


\section{Johan M. Strijdom}

Augustine, Chidester finds at crucial moments a synthesis of perceptual metaphors to express the individual's encounter with God, although he notes that whereas the early Augustine within a monastic environment focused on contemplation associated with sight, he later came to prioritize the hearing of God's Word in the city due to his confrontation as bishop with the harsh realities of his congregation in Hippo.

In his early reflection on the senses, Augustine importantly distinguished between the five senses, an 'interior sense' and reason, above and beyond which was God as eternal truth. The ultimate goal, he thought at that stage of his life, was the rational vision of God guided by faith, 'the conjunction of seer and seen', where 'seeing God was...to enter into the being of God' (Chidester 2000a:130). His Christian epistemology maintained at that stage that hearing words alone was not sufficient to convey information, but that one would learn only 'by seeing directly the things to which the words referred' (Chidester 2000a:131; emphasis added). Concerning an interior sense, he held that this was crucial for intellectual vision or insight. 'The mind', he argued, 'required an inner teacher, the interior magister, who would display the truth [i.e. Christ] directly to the eye of the mind' (Chidester 2000a:131). Christ was thus teaching within the human mind.

For Chidester, the respective views of the role of the senses in education by Bonaventure and Melanchthon illustrate two opposite trajectories in which Augustine came to be appropriated. Whereas the $13^{\text {th }}$-century monk prioritized seeing and being illuminated by God's Light through contemplation, the $16^{\text {th }}$-century reformer and rhetorician emphasized hearing God's Word and action.

In Word and light, Chidester's analysis of the senses of seeing and hearing and their metaphorical uses in European Christian discourses is clearly structuralist, phenomenological, and descriptive, but it is always historically and culturally nuanced. He summarizes his approach at the time as follows:

A phenomenology of perception must be sensitive to the ways in which the senses were understood to operate within specific historical and cultural contexts. Culturally constructed assumptions regarding the operations of the senses, the ways in which they structure information,

his mouth like birds made of precious stones entering the ears of those who listened carefully (cf. Chidester 1992:20; 2000a:119-120). 
'Senses': Assessing a Key Term in David Chidester's Analysis of Religion

and the ways in which they orient human consciousness, are particularly important in a historical phenomenology of perception (Chidester 1992:2).

In Christianity: A global history, published in 2000 (eight years after Word and light), Chidester does not use 'the senses' as an organizing category of analysis. A close reading of this later work nevertheless shows the extent to which this aspect plays a role in his reading of Christian history. I will mention a few instances from late-medieval Eastern Greek Orthodox and Western Latin Catholic traditions, in which he pays particular attention to the visions of mystics of the period.

From the $10^{\text {th }}$ to the $14^{\text {th }}$ century, the Eastern Orthodox church, drawing on the mystical theology of the $6^{\text {th }}$-century Dionysius the Areopagite and the $4^{\text {th }}$-century Cappadocian fathers, developed an elaborate theory and practice of the soul ascending to be united with God as the ultimate Light. By cultivating in monasteries a personal, inner contemplation through ritual techniques of the body (such as a sitting physical posture accompanied by repetitive silent prayer coordinated with rhythmic breathing), monks would induce a mystical experience understood as a deification (theōsis) of the soul during which God as the Light (the Phōs) was directly seen. Although the practice of hesychasm (silent prayer) accompanied by the beard resting on the chest with the eyes focusing on the navel was ridiculed as superstitious 'navelgazing' by the $14^{\text {th }}$-century Baarlam of Calabria, the defense of the technique by the monk, Gregory Palamas of Athos, was accepted by the $14^{\text {th }}$-century Orthodox church councils. If Baarlam argued on the basis of Dionysius the Areopagite that God was hidden and could not be seen directly by humans, but could only be known indirectly through the Scriptures, sacraments, and tradition, Gregory Palamas, on the basis of the same source, held that though humans could not grasp the essence of God, they could directly experience the energy of the divine Light 'in the brilliant darkness of a hidden silence' (Gregory Palamas, quoted in Chidester 2000a:247). By means of the bodily techniques of hesychasm, the Orthodox church continued to maintain that body and soul could journey upwards to see and be united with God as the ultimate Light. The sense of sight, specifically as an internal contemplative sense, was thus cultivated in late-medieval Greek Orthodox monasteries through specific bodily techniques to mediate a mystic union with God who was conceived of as Light. 
In the Latin West, in $12^{\text {th }}$-century France, within a monastic context of monks, Bernard of Clairvaux developed Dionysius the Areopagite's mystical theology by using metaphors of intimate erotic passion, based on an allegorical reading of the biblical Song of Songs, to theorize the ascent of the individual soul to its deification in an ecstatic, direct union with Christ. Driven by love in its upward movement through the three stages of confession, devotion, and contemplation, he held, the soul first kissed the feet and then the hands of Christ in preparation for the ultimate kiss on the mouth of Christ, the Divine Lover. 'By loving, desiring, and adhering to God in this passionate embrace, Bernard concluded, the soul achieved the vision of God' (Chidester 2000a:240).

In contrast to Bernard and other monks of the $12^{\text {th }}$ and $13^{\text {th }}$ century who only theorized by means of erotic metaphors the soul's ascent to and unification with Christ without claiming to have actually seen extraordinary visions or to have heard supernatural voices themselves, female mystics expressly claimed such intimate, spiritual experiences. After establishing a convent, Hildegard of Bingen recorded and elaborated in a mystical theology what she saw and heard during her intense personal encounters with God, and composed hymns claiming that 'the divine light' entered her 'spiritual ears as music, as heavenly singing, as a divine symphony, as a celestial harmony' (Chidester 2000a:243).

Outside the context of the convent, living in ordinary houses in cities in $13^{\text {th }}$-century Belgium, the Netherlands, the Rhineland, and Northern France, unmarried women known as Beguines, cultivated an erotically charged mystical practice and theologia negativa of the soul's ascent that challenged and attempted to reverse the church's system of patriarchal domination. When these women opened their mouths to kiss Christ their bridegroom, melting with him, falling into an abyss and annihilating their individual identities at the apex of the ascent of the soul, Chidester (2000a:250-251) remarks, this intense intimacy and experience of nothingness in their spiritual visions and direct union with Christ subverted the church's prescription of closed mouths and bodies for women. In the case of the French Beguine, Marguerite Porete, the defiance of male ecclesiastical authority on the basis of her mystical theology of nothingness resulted in her condemnation by the ecclesiastical court as 'an unrepentant heretic and a "pseudo-woman" and being handed over "to the secular authorities of Paris to be burned on June 1, 1310' (Chidester 2000a:253). 
More than a century later, in the $15^{\text {th }}$-century Renaissance Florence, Christian Platonists, particularly Marsilio Ficino and Pico della Mirandola, sponsored by wealthy de Medici patrons, drew inspiration for their thinking about 'the senses' not only from Platonist and Neoplatonist philosophers ${ }^{13}$ due to an encounter with contemporary Byzantine scholars, but also from earlier Muslim interpretations of Aristotle by the $11^{\text {th }}$-century Ibn Sina (Avicenna) and the $12^{\text {th }}$-century Ibn Rushd (Averroes). Pico, in addition, drew on Kabbalah traditions, which led to his condemnation as heretic by the church.

Foregrounding the sense of immediate 'sight', Ficino insisted that words alone are not sufficient to exhort human beings to a moral life. What was needed was an image of virtue 'placed before the eye', of which meditation on Botticelli's paintings of Venus understood as an allegory of the humane virtues of love, dignity, modesty, etc. could have served as model (Chidester 2000a:293-294). Within his tripartite concept of the self, thought of as harboring the heavenly bodies with their conflicts and harmony, a spiritual faculty in the middle of the self was conceived of as having the capacity to move upwards to heaven 'toward supra-intelligible things', or downwards to earth '[giving] birth to the charm of sensible things in matter' - a process symbolized by an allegorical understanding of Venus (Ficino, quoted in Chidester 2000a:295).

This view of the self clearly drew on a Platonic dualism, but the Christian Platonists also developed medieval interpretations of Aristotle by Ibn Sina and Ibn Rushd which combined elements from Plato, Aristotle, and the Stoics. Based on these Muslim interpreters of Aristotle, it was generally accepted that humans had three souls:

- at the lowest end, a vegetative soul that gives life to the body by letting it grow and reproduce;

- at the highest end, an intellective soul where information is first received from the senses by a passive intellect and then transformed into rational concepts/ideas by an active intellect; and

- between these two souls, a sensitive soul that consists of faculties that interact with both the lower and higher souls.

13 Of particular importance was their appropriation of the $3^{\text {rd }}$-century Neoplatonic corpus hermeticum, with Hermes, Orpheus, and Zoroaster as crucial figures, that they thought of as ancient wisdom going back to Moses. 


\section{Johan M. Strijdom}

This intermediate sensitive soul, in its interaction with the vegetative soul at the lowest end, was considered not only to govern movements of the body, but also to govern and be driven by the basic emotional desires of sex and aggression. In its interaction with the intellective soul at the highest end, the sensitive soul was considered to contain faculties of perception that not only include the five external senses through which objects are perceived, but crucially also, internal senses that enable humans to perceive in their imagination objects that are absent. It is these latter higher imaginative capacities of the sensitive soul' that the Christian Platonists of the Renaissance referred to as 'spirit' (Chidester 2000a:303).

By the end of the $15^{\text {th }}$ century, the monk, Savonarola, invited to Florence by Lorenzo de Medici, based his apocalyptic sermons on his own visions of divine anger and divine mercy. On the one hand, God was ready to destroy the world with his anger centered on Rome, but his sword also raised over Florence. The need to repent and reform Florence was urgent. On the other hand, Savonarola also saw a radiant, golden cross centered on Jerusalem, which symbolized God's mercy for the world. If the first vision announced purifying punishment, the second promised subsequent peace - a pattern that was clearly derived from the book of Revelation. However, when the king of France entered Florence in 1494 and got rid of the Medicis, Savonarola established a theocratic government with Florence as chosen city and the French Charles VIII as divine king - a political program that Savonarola based on a new vision, according to which he ascended to paradise, where he met several women and was led to the throne of the Virgin Mary, who intervened with the Trinity on behalf of Savonarola and Florence. It is thus clear that Savonarola not only developed 'basic Christian millennial themes', but also showed himself to be 'adept in the rhetorical use of powerful visual imagery. His preaching was based on mobilizing imagery' (Chidester 2000a:309). Although he agreed with Christian Platonists in Florence on the importance of visual imagery, he differed from them by insisting that artists should only depict Christian images, and organized the burning of books and paintings of nude men and women that he considered obscene. When political conditions again changed in Florence, with French support failing to arrive, Savonarola was left vulnerable. He was excommunicated by the pope and burned on May 23, 1498 in the same public square where he had earlier burned those books and paintings. In the case of Savonarola, the political function of visions, conceived of as a form of internal sight, is clear. 
With the advent of the new medium of print, apocalyptic visions could be distributed more widely. When, in 1522, 'a deformed fetus was found in the uterus of a cow in the German region of Saxony', the news was widely publicized in Italy, where a journalist of Modena interpreted it as 'a sign of the disturbances, evil, and heresy that could be expected at the end of the world', specifically as a representation of 'a friar...Martin Utero, who...preached heresy in Germany', referring of course to 'the reformer Martin Luther, who...was actively mobilizing a religious revolution in Germany' (Chidester 2000a:311).

\section{Second case study: The 'senses' in South African indigenous traditions}

In the concluding chapter of Word and light, Chidester (1992:131-134) notes Foucault's thesis in The order of things, that the modern era radically broke with the Middle Ages by separating the synesthetic unity of the senses of sight and hearing. According to Foucault, two modern epistemologies can be distinguished on the basis of different perceptual orientations: In the $17^{\text {th }}$ and $18^{\text {th }}$ centuries, the emphasis was on knowledge obtained from seeing, institutionalized in the modern prison, clinic, and asylum that subjected human bodies to visual observation ('the tyranny of the eye'); in the $19^{\text {th }}$ century, the focus shifted to knowledge acquired through hearing, which characterized emerging $19^{\text {th }}$-century disciplines with their focus on the study of historical change and theories of evolutionary progress.

Even if one has reservations about the validity of generalizations such as these, Chidester holds, they prompt us to focus on the role of the senses in our study of religious traditions within specific historical and geographical contexts. This attention to the senses should include not only an analysis of their metaphorical uses in religious discourses, but also of their mediating role in the performance of ritual practices to unify a group and of the negotiation of their ownership in power struggles among contending groups and their legitimization by dominant institutions (Chidester 1992:142-144).

As we turn to Chidester's analysis of indigenous religions in South Africa and their interpretation by imperial theorists, in which ways does his concern with 'the senses' as key term throw new light in this case? 
In Empire of religion (Chidester 2014), he argues that the $19^{\text {th }}$-century anthropologist, E.B. Tylor's evolutionary theory of the origin of religion was based on a decontextualized and distorted reading of the data. According to Tylor, religious belief emerged in the mind of primitive human beings who were unable to distinguish between dreams and reality ('waking consciousness'). When they saw dead relatives in their dreams, they simply assumed that they were still alive as spirits. As evidence of the survival of this primitive mentality of animism, Tylor used reports on Zulu dreaming in Henry Callaway's Religious system of the Amazulu (1868-1870), highlighting specifically the instance of a Zulu diviner who described himself as having been overwhelmed by visions of ancestral spirits to such an extent that his body had become a 'house of dreams' (Chidester 2005:112).

In 1871, Callaway himself, the colonial missionary among the Zulu, read a paper in London, in which he explained and illustrated dreams and visions with reference to the Zulu, as a subjective 'brain sensation' in which the brain, 'without external causes in operation, is attended by feeling, hearing and sight, just as it would if there were external causes in operation, capable of producing such sensations' (Callaway, quoted in Chidester 2014:119). In dreams and visions the brain thus has sensations of sight and hearing, as if they really enter through the eye and ear - a condition of the brain that Zulu diviners were, according to Callaway, quite apt at cultivating by 'self-mesmerism'. Callaway's analysis too, Chidester (2014:120) holds, 'did not do justice to his data'.

To do justice to the data, Chidester insists, one must interpret the report on Zulu dreaming in Callaway's Religious system within its colonial context. The report on the Zulu diviner in Callaway is actually given by his Zulu convert and assistant Mpengula Mbande, who was himself struggling with his ambiguous position as Christian. Most importantly, the Zulu diviner stated that in becoming a 'house of dreams' the ancestral spirits came to kill him. Under colonial conditions, due to dispossession of cattle and dislocation from ancestral land, it became increasingly difficult for descendants to heed the demands of ancestors in dreams for sacrifice and to perform rituals in which the spirits of deceased ancestors were to be brought home. Special rituals were therefore developed in an attempt to prevent demanding and threatening ancestral spirits from appearing to descendants in dreams.

Under contemporary global conditions, Chidester (2012:112-131) proposes in Wild religion, on the basis of an analysis of several Zulu 
neoshamans (including Credo Mutwa and so-called white sangomas), that these traditional elements of sacrificial exchange and territorial orientation are echoed, but they have changed in crucial ways. By examining the role of the human senses and electronic media as extended senses in a 'new Zulu dreamscape', Chidester (2012:114-115, 131) argues that although Zulu neoshamans occasionally see the five senses and new media as limiting the potential to dream and have visions of the ancestors, they have come to optimally exploit their potential for intense sensory experiences and authentication of their practices. Importantly, contrary to $19^{\text {th }}$-century attempts by Zulu speakers to turn off or block ancestral dreams as a 'sensory medium', contemporary Zulu neoshamans cultivate 'a sensory extravagance, an overabundance of sensory engagements with things that are not there', but that they regard as real and engage accordingly (Chidester 2012:130-131).

Sacrificial exchange is now located 'in the dilemmas posed by the global economy', which is 'not only defined by the increased pace and scope of the flows of money, technology, and people', but also by 'new mediated images and ideals of human possibility, including the possibility that occult forces are both shadow and substance of global economic exchange' (Chidester 2012:114). Credo Mutwa, for example, came to 'deal with these dilemmas of the global economy by identifying aliens from outer space as the nexus of a sacrificial exchange into which he has entered by eating extraterrestrial beings in a sacramental meal and by being their sacrificial victim' (Chidester 2012:114).

The traditional spatial orientation of bringing ancestors home has, however, developed differently for Mutwa on the one hand and white South African sangomas living in North America on the other hand. Although Mutwa tried to relocate his ancestral home to several places in South Africa, he eventually found a home on the internet that has given him access to a global network of neoshamanic and New Age enthusiasts (notably David Icke who found in Mutwa confirmation of his conspiracy theory of the Illuminati). The white Zulu neoshamans in North America, however, found in the internet a new global medium to come home to Africa by conceiving of their dreams as calls by African ancestors helping them to overcome their previous alienation from Africa due to the apartheid system. 


\section{Conclusion}

What have we, in terms of the framework of Meyer and Verrips ${ }^{14}$, learned from Chidester's analysis of religion, that is new? And how can we take Chidester's analysis further?

- Sensorial metaphors: Like Meyer and Verrips, Chidester insists that the experience of the sacred is mediated through the bodily senses. However, on the basis of his case studies from the Christian tradition, his argument extends theirs not only by positing that sensorial mediations structure our orientation to the world differently, depending on whether the sense of sight or hearing is prioritized, but also by demonstrating how the meanings/connotations/associations that cultures attribute to and construct around these physical senses, constitute the basis of their use as perceptual metaphors.

- Inner senses of mystics and shamans: Like Meyer and Verrips, Chidester insists on the importance of examining not only elitist and dominant, but also popular and marginal forms of religion - illustrated notably by his focus on the role of dreaming and electronic media in Zulu neoshamanism. By considering the visions and dreams of mystics and shamans as interior senses that should be considered part of the bodily mediation of religion, though, Chidester foregrounds a point that is mentioned only in passing by Meyer and Verrips.

- Historical contexts and the possibility of critique: Chidester would agree with Meyer and Verrips that the individual self is formed through habitual uses of the senses, and that legitimate ways in which the senses may mediate an encounter with the sacred are determined by religious authorities. However, his analysis of historical and contemporary examples focuses on changing roles of the senses in religion within changing historical contexts in a way that a synchronic analysis does not offer.

14 I emphasize again that, in this essay, I have only used this article by Meyer and Verrips without engaging with their development of the themes elsewhere in their work. The purpose is to use their article as a frame of reference to highlight issues that Chidester has elaborated on in his work, without denying that Meyer and Verrips might have done so in their own ways elsewhere in their oeuvre. 
At this point I would like to raise two considerations regarding power relations in the use of the senses in religion for further attention. Meyer and Verrips note that collective identities are formed by the shared uses of the senses, but that this aspect needs further investigation. In Authentic fakes, published in 2005, Chidester indeed employs the term 'sociality' to forms of popular culture that function like religions, and considers critiques of the drawing of exclusionary and inclusive collective boundaries. In previous publications I have argued that his argument in these cases has not been consistent and calls for making explicit the normative framework from which one judges boundary formations by groups (cf. Strijdom 2012).

In the same book, Chidester applies the term 'exchange' to a selection of forms of popular cultures, but here too his critical engagement with economic systems is not consistent. On the one hand he seems to be quite sympathetic with the Rock ' $n$ ' Roll ideology of sharing resources, but on the other hand, in his analysis of the 2010 World Cup in South Africa as functioning like a religion, he seems to consider Bataille's view of the sacred as the excessive waste of resources as necessary for a culture to be creative and thrive. Again, an explication of a normative framework and its consistent application in developing a critique would be necessary (cf. Strijdom 2014b).

In the Preface to Word and light, Chidester (1992:xiii-xiv) notes that he started his exploration of the senses and perceptual metaphors 'in a more innocent time', in which he focused on metaphors of seeing and hearing as the most important perceptual metaphors in religious discourse. His move from the USA to the harsh realities of a violent South Africa, however, has forced him to redirect his research from the meaning of symbols to their power, in which attention to tactile metaphors of 'opposition and resistance' became more pressing. In his subsequent work, Chidester indeed does not hesitate to critique the systemic injustice of apartheid and colonialism, as well as the complicity of religious studies in these projects. In this article, I have not only shown ways in which Chidester has continued to explore the senses in religion, but also hinted at ways in which his analysis has not been consistent and calls for further thinking. 


\section{References}

Chidester, D. 1992. Word and light: Seeing, hearing, and religious discourse. Chicago: University of Illinois Press.

Chidester, D. 1996. Savage systems: Colonialism and comparative religion in Southern Africa. Charlottesville: University Press of Virginia.

Chidester, D. 2000a. Christianity: A global history. London, San Francisco: Penguin \& HarperCollins.

Chidester, D. 2000b. Material terms for the study of religion. Journal of the American Academy of Religion 68, 2: 367-379.

Chidester, D. 2005. Authentic fakes: Religion and American popular culture. University of California Press: Berkeley.

Chidester, D. 2012. Wild religion: Tracking the sacred in South Africa. Oakland: University of California Press.

Chidester, D. 2013. Postgraduates producing knowledge. Journal for the Study of Religion 26, 1:5-7.

Chidester, D. 2014. Empire of religion: Imperialism and comparative religion. Chicago: University of Chicago Press.

Chidester, D. 2015. Material culture. In Segal, R. \& K. von Stuckrad (eds.): Vocabulary for the study of religion. Vol 2. Leiden: Brill.

Chidester, D. 2018. Religion: Material dynamics. Oakland: University of California Press.

Hirschkind, C. 2006. The ethical soundscape: Cassette sermons and Islamic counterpublics. New York: Columbia University Press.

Houtman, D. \& B. Meyer (eds.) 2012. Things: Religion and the question of materiality. New York: Fordham University Press.

McLuhan, M. 1964. Understanding media: The extensions of Man. Cambridge: MIT Press.

Meyer, B. \& J. Verrips 2008. Aesthetics. In Morgan, D. (ed.): Key words in religion, media and culture. New York: Routledge.

Morgan, D. 1998. Visual piety: A history and theory of popular religious images. Berkeley: University of California Press.

Pinney, C. 2004. 'Photos of the gods': The printed image and political struggle in India. London: Reaktion.

Strijdom, J.M. 2012. Problems with indigeneity: Fragmentation, discrimination and exclusion in post-colonial African states. Image \& Text 19: 24-32. 
'Senses': Assessing a Key Term in David Chidester's Analysis of Religion

Strijdom, J.M. 2014a. The material turn in religious studies and the possibility of critique: Assessing Chidester's analysis of 'the fetish'. HTS Teologiese Studies/Theological Studies 70, 1: 7 pages. Art. \#2116. DOI: http://dx.doi.org/10.4102/hts.v70i1.2116

Strijdom, J.M. 2014b. Uses of social theory in comparative religious studies: Assessing Chidester's sociological analysis of 'Wild religion' in postapartheid South Africa. Journal for the Study of Religion 27, 2: 10-24.

Johan M. Strijdom

Religious Studies

University of South Africa

strijjm@hotmail.com; strijjm@unisa.ac.za 